\title{
Unearthing Bundles of Baffling Silences: The Entangled and Racialized Global Histories of Media and Media Studies
}

\section{Wendy Willems \\ London School of Economics, w.willems@lse.ac.uk}

As Michel-Rolph Trouillot argued, "any historical narrative is a particular bundle of silences." ${ }^{1}$ This also applies to the way we narrate the history of media institutions and technologies, as well as to how we document the historical emergence of the field of media and communication studies. A key task of media historians should be to unearth the field's multiple silences and to reveal how these are linked to the exercise of power as, in Trouillot's words, "the ultimate mark of power may be its invisibility; the ultimate challenge, the exposition of its roots." 2

In a 2014 Communication Theory article entitled "Provincializing Hegemonic Histories of Media and Communication Studies: Toward a Genealogy of Epistemic Resistance in Africa," I critiqued how calls for the "internationalizing" or "de-Westernizing" of media and communication studies implicitly silence a much longer history of media and communication studies outside the so-called West. ${ }^{3}$ I argued that these calls suggested that scholars in the non-West had somehow not previously engaged in critical knowledge production on media and communication. My article reinscribed the epistemological and historical foundations of media and communication studies in Africa, which hegemonic histories of the field had marginalized. It called for an acknowledgment of the multiple genealogies of media and communication studies in different parts of the world.
Wendy Willems, "Unearthing Bundles of Baffling Silences: The Entangled and Racialized Global Histories of Media and Media Studies," History of Media Studies 1 (2021), https://doi.org/ 10.32376/d895aoea.52801916.

\section{(c) (1) (8)}

${ }^{1}$ Michel-Rolph Trouillot, Silencing the Past: Power and the Production of History (Boston, MA: Beacon Press, 1995), 27.

${ }^{2}$ Trouillot, Silencing the Past, xix.

\footnotetext{
${ }^{3}$ Wendy Willems, "Provincializing Hegemonic Histories of Media and Communication Studies: Toward a Genealogy of Epistemic Resistance in Africa," Communication Theory 24, no. 4 (2014): 415-34.
} 
Since my article's publication, demands for internationalization and de-Westernization have increasingly been replaced with calls for "decolonization" in the wake of the 2015 \#RhodesMustFall protests at the University of Cape Town and other universities across the globe, as well as following the 2015 and 2020 \#BlackLivesMatter protests. Demonstrations have pointed to the need for universities to transform in a number of ways, including teaching more diverse curricula, making higher education more accessible to students from marginalized economic backgrounds, revising teaching methodologies and research ethics to render them more democratic and less hierarchical, hiring a diverse pool of faculty, and addressing how universities have benefited from slavery or fed into colonialism through eugenics and scientific racism, as well as the need for reparations. Again, it is important to acknowledge here the longer genealogy of demands for decolonization and liberation in the African context, ranging from $\mathrm{W}$. E. B. Du Bois to Frantz Fanon to Ngũgĩ wa Thiong'o.

These calls for decolonization have provoked a response in our field, primarily from U.S.-based, African, and Latin American scholars who-if somewhat separately-have drawn attention to a multitude of problem areas:4 the continued marginalization of scholars of color in publication rates, citation rates, and editorial journal positions; ${ }^{5}$ the need for systemic redress; ${ }^{6}$ the silence on the history of European and American imperialism in graduate communication studies syllabi and canonical texts in media and communications; ${ }^{7}$ the characterization of research on media, communication, and race as addressing peripheral rather than core issues; ${ }^{8}$ the need to center Africa in media and communication studies and to problematize claims to universality in much of the work focused on the United States and Europe; ${ }^{9}$ the marginalization of African media studies in the U.S. academy; ${ }^{10}$ and the relevance of decolonial approaches in making sense of media and communications in Africa and the Global South. ${ }^{11}$

This body of work has once more highlighted that our field has always been raced, ${ }^{12}$ as evidenced by the white vantage points (presumed to be universal) adopted in canonical texts centered in the field, as well as by the longer history of institutionally racist practices in universities, journals, and professional associations. While both the older and newer calls for decolonization may have different meanings in distinct geographical contexts, they are ultimately connected in their response to the afterlives of shared racialized histories of slavery and colonialism and their contestation of anti-Blackness and anti-Indigeneity in various parts of the world.

These studies offer much food for thought to historians of media and media studies. They point to the need for more inclusive and
${ }^{4}$ See, for example, the discussions within the Communication and Decoloniality Working Group as part of the Latin American Association of Communication Researchers (ALAIC) conference, University of Costa Rica, July 30-August 1, 2018, https://www.alaic.org/site/wpcontent/uploads/2018/o6/GI_4.pdf (last accessed September 1, 2021).

${ }_{5}$ Paula Chakravartty, Rachel Kuo, Victoria Grubbs, and Charlton McIlwain, "\#CommunicationSoWhite," Journal of Communication 68, no. 2 (2018): 254-66.

${ }^{6}$ Eve $\mathrm{Ng}$, Khadijah Costley White, and Anamik Saha, "\#CommunicationSoWhite: Race and Power in the Academy and Beyond," Communication, Culture and Critique 13, no. 2 (2020):

143-51.

${ }^{7}$ For the silence on imperialism in graduate syllabi, see Paula Chakravartty and Sarah J. Jackson, "The Disavowal of Race in Communication Theory," Communication and Critical/Cultural Studies 17, no. 2 (2020): 210-19. For the silence on imperialism in canonical texts, see Roopali Mukherjee, “Of Experts and Tokens: Mapping a Critical Race Archaeology of Communication," Communication, Culture and Critique 13, no. 2 (2020): 152-67.

${ }^{8}$ Mukherjee, “Of Experts and Tokens." 
complicated histories of our field, ones that acknowledge both its multiple global origins and the racialized history of media and media studies. Yet increasingly, the notion of decolonization runs the risk of turning into an empty metaphor, 9 used to tick boxes or to attract new pools of student customers who can populate a diverse classroom that will enhance the competitiveness of the neoliberal university. Too frequently, the call for decolonization translates into a call for diversity and inclusion. While the latter are important, it is crucial to go a step further and ask how the act of including different vantage points challenges, subverts, and problematizes dominant theoretical approaches and concepts, received histories, and canonical texts in our field.

Armond Towns offers a good start here in critiquing both the way in which media history has been written and how received histories have become canonized in the field. ${ }^{13}$ His work on Marshall McLuhan shows McLuhan's failure to acknowledge the crucial role of Black bodies in the emergence of Western media technologies. Relatedly, while media historians might have examined how the BBC promoted the idea of Empire through its overseas service, they have less frequently asked how histories of slavery and colonialism enabled the institution's emergence, and what implications this question might have for debates on reparations.

Similarly, Gurminder K. Bhambra highlights the erasure of slavery and colonialism in the Frankfurt School's theorization of modernity. ${ }^{14}$ As she argues, modernity did not "emerge from separation or rupture, but through the connected and entangled histories of European colonization." 15 What, for example, would Jürgen Habermas's eighteenth-century European public sphere look like if its emergence had been understood in the context of slavery and the slave trade? While the role of media and technology in perpetuating racism is relatively well documented, media and communication studies has yet to acknowledge the constitutive nature of race, ${ }^{16}$ recognizing how histories of slavery and colonialism made possible particular media institutions and technologies.

The intimate histories extant among Africa, Europe, and the United States do not only relate to the history of media institutions and technologies but also to that of media and communication studies as a field. In his work on McLuhan, Towns highlights how McLuhan appropriated the racist ideas of John Carothers on "the African mind." 17 Carothers was a British psychiatrist who worked for the Kenyan colonial government. Other influential scholars in our field built their careers drawing on fieldwork in Africa. For example, Leonard W. Doob, a psychologist at Yale University associated with the field of cognitive psychology and propaganda studies, re-
9 Bruce Mutsvairo, Palgrave Handbook of Media and Communication Research in Africa (London: Palgrave Macmillan, 2018). Winston Mano and viola c. milton, Routledge Handbook of African Media and Communication Studies (London: Routledge, 2021).

${ }^{10}$ Moradewun Adejunmobi, "African Media Studies and Marginality at the Center," Black Camera 7, no. 2 (2016): 125-39. Wunpini F. Mohammed, "Decolonizing African Media Studies," Howard Journal of Communications, 32, no. 2 (2021): 123-38.

${ }^{9}$ Eve Tuck and K. Wayne Yang, "Decolonization Is Not a Metaphor,"

Decolonization: Indigeneity, Education, and Society 1, no. I (2012): 1-40.

${ }^{11}$ Sarah Chiumbu and Mehita Iqani, Media Studies: Critical African and Decolonial Approaches (Cape Town: Oxford University Press, 2019). Last Moyo, The Decolonial Turn in Media Studies in Africa and the Global South (London: Palgrave, 2020). Kebhuma Langmia and Agnes L. Lando, Digital Communications at Crossroads in Africa: A Decolonial Approach (New York: Palgrave MacMillan, 2020).

${ }^{12}$ See also Judith N. Martin and Thomas K. Nakayama, "Communication as Raced," in Communication As . .., ed. Gregory J. Shepherd et al. (New York: Sage, 2006), 75-83.

${ }^{13}$ Armond Towns, "The (Black) Elephant in the Room: McLuhan and the Racial," Canadian Journal of Communication 44, no. 4 (2019): 545-54.

${ }^{14}$ Gurminder K. Bhambra, "Decolonizing Critical Theory? Epistemological Justice, Progress, Reparations," Critical Times 4, no. 1 (2021): 73-89.

${ }^{15}$ Bhambra, "Decolonizing Critical Theory?" 81.

${ }^{16}$ See also Lyndsey Beutin, "Sylvia Wynter and the History of Communication: A New World View," paper presented at the virtual ICA preconference "Exclusions in the History and Historiography of Communication Studies," May 26-27, 2021.

${ }^{17}$ Towns, "The (Black) Elephant in the Room." 
searched the link between media and modernization. In his book Communication in Africa: A Search for Boundaries, one of the first academic monographs on communication in Africa, Doob discusses the sociocultural, linguistic, and psychological variables impinging on communication patterns in Africa. ${ }^{18}$ In other work, Doob sought to measure the levels of "psychological modernisation" in Africa and to assess the role of media in the process of modernization based on empirical research in Kenya, Tanzania, Uganda, and Somalia. ${ }^{19}$

A number of studies have situated the work of modernization scholars such as Wilbur Schramm and Daniel Lerner within the political context of the Cold War, but less often have commentators viewed those scholars' research through the prism of race or sufficiently examined how their fieldwork in Africa shaped both their individual careers and early formations of media and communications studies on the African continent. Doing so would offer us a better understanding of the racialized and entangled histories of media and communication studies across different continents.

\section{Bibliography}

Adejunmobi, Moradewun. "African Media Studies and Marginality at the Center." Black Camera 7, no. 2 (2016): 125-39. https:// muse. jhu.edu/article/619765.

Beutin, Lyndsey. "Sylvia Wynter and the History of Communication: A New World View," paper presented at the virtual ICA preconference "Exclusions in the History and Historiography of Communication Studies," May 26-27, 2021.

Bhambra, Gurminder K. "Decolonizing Critical Theory? Epistemological Justice, Progress, Reparations." Critical Times 4, no. I (2021): 73-89. https : //doi . org/10. 1215/26410478-8855227.

Chakravartty, Paula, and Sarah J. Jackson. "The Disavowal of Race in Communication Theory." Communication and Critical/Cultural Studies 17, no. 2 (2020): 210-19. https://doi.org/10.1080/ 14791420.2020 .1771743$.

Chakravartty, Paula, Rachel Kuo, Victoria Grubbs, and Charlton McIlwain. "\#CommunicationSoWhite." Journal of Communication 68, no. 2 (2018): 254-66. https://doi.org/10.1093/joc/jqy003.

Chiumbu, Sarah, and Mehita Iqani. Media Studies: Critical African and Decolonial Approaches. Cape Town: Oxford University Press, 2019.

Doob, Leonard W. Communication in Africa: A Search for Boundaries. New Haven, CT: Yale University Press, 1961.

—. "Scales for Assaying Psychological Modernization in Africa." Public Opinion Quarterly 31, no. 3 (1967): 414-21. https://doi. org/10. 1086/267540.

History of Media Studies, vol. 1, 2021

\footnotetext{
${ }^{18}$ Leonard W. Doob, Communication in Africa: A Search for Boundaries (New Haven, CT: Yale University Press, 1961).

${ }^{19}$ Leonard, W. Doob, "Scales for Assaying Psychological Modernization in Africa," Public Opinion Quarterly 31, no. 3 (1967): 414-21.
} 
Langmia, Kebhuma, and Agnes L. Lando. Digital Communications at Crossroads in Africa: A Decolonial Approach. New York: Palgrave MacMillan, 2020.

Mano, Winston, and viola c. milton. Routledge Handbook of African Media and Communication Studies. London: Routledge, 2021.

Martin, Judith N., and Thomas K. Nakayama. "Communication as Raced." In Communication As . . ., edited by Gregory J. Shepherd, Jeffrey St. John, and Ted Striphas, 75-83. New York: Sage, 2006.

Mohammed, Wunpini F. "Decolonizing African Media Studies." Howard Journal of Communications, 32, no. 2 (2021): 123-38. https://doi. org/10.1080/10646175.2021. 1871868.

Moyo, Last. The Decolonial Turn in Media Studies in Africa and the Global South. London: Palgrave, 2020.

Mukherjee, Roopali. "Of Experts and Tokens: Mapping a Critical Race Archaeology of Communication." Communication, Culture and Critique 13, no. 2 (2020): 152-67. https://doi.org/10.1093/ $\mathrm{ccc} /$ tcaa009.

Mutsvairo, Bruce. Palgrave Handbook of Media and Communication Research in Africa. London: Palgrave Macmillan, 2018.

$\mathrm{Ng}$, Eve, Khadijah Costley White, and Anamik Saha. "\#CommunicationSoWhite: Race and Power in the Academy and Beyond." Communication, Culture and Critique 13, no. 2 (2020): 143-51. https://doi.org/10.1093/ccc/tcaa011.

Towns, Armond. "The (Black) Elephant in the Room: McLuhan and the Racial." Canadian Journal of Communication 44, no. 4 (2019): 545-54. https://doi.org/10.22230/cj c.2019v44n4a3721.

Trouillot, Michel-Rolph. Silencing the Past: Power and the Production of History. Boston, MA: Beacon Press, 1995.

Tuck, Eve, and K. Wayne Yang. "Decolonization Is Not a Metaphor." Decolonization: Indigeneity, Education, and Society 1, no. 1 (2012): 140. https://jps.library.utoronto.ca/index.php/des/article/ view/18630/15554.

Willems, Wendy. "Provincializing Hegemonic Histories of Media and Communication Studies: Toward a Genealogy of Epistemic Resistance in Africa." Communication Theory 24, no. 4 (2014): 41534. https://doi.org/10.1111/comt. 12043.

History of Media Studies, vol. 1, 2021 